\title{
Plant growth and soil microbial community structure of legumes and grasses grown in monoculture or mixture
}

\author{
CHEN Meimei ${ }^{1}$, CHEN Baodong ${ }^{1, *}$, MARSCHNER Petra ${ }^{2}$ \\ 1. Department of Soil Environmental Science, Research Center for Eco-Environmental Sciences, The Chinese Academy of Sciences, \\ Beijing 100085, China.E-mail: chenmeim@mails.gucas.ac.cn \\ 2. Soil and Land System, School of Earth and Environmental Sciences, The University of Adelaide, Adelaide 5005, Australia
}

Received 25 October 2007; revised 5 December 2007; accepted 7 January 2008

\begin{abstract}
A greenhouse pot experiment was conducted to investigate the influence of soil moisture content on plant growth and the rhizosphere microbial community structure of four plant species (white clover, alfalfa, sudan grass, tall fescue), grown individually or in a mixture. The soil moisture content was adjusted to $55 \%$ or $80 \%$ water holding capacity (WHC). The results indicated that the total plant biomass of one pot was lower at 55\% WHC. At a given soil moisture, the total plant biomass of white clover and tall fescue in the mixture was lower than that in a monoculture, indicating their poor competitiveness. For leguminous plants, the decrease in soil moisture reduced the total microbial biomass, bacterial biomass, fungal biomass, and fungal/bacterial ratio in soil as assessed by the phospholipid fatty acid analysis, whereas, lower soil moisture increased those parameters in the tall fescue. The microbial biomass in the soil with legumes was higher than that in the soil with grasses and the two plant groups differed in soil microbial community composition. At high soil moisture content, microbial communities of the plant mixture were similar to those of the legume monoculture, and the existence of legumes in the mixture enhanced the bacterial and fungal biomass in the soil compared to the grasses grown in the monoculture, indicating that legumes played a dominant role in the soil microbial community changes in the plant mixture.
\end{abstract}

Key words: legumes; grasses; the Chinese Loess Plateau; microbial communities; phospholipid fatty acid (PLFA)

\section{Introduction}

Soil microorganisms play important roles in soil ecosystem processes, such as, nutrient cycling, organic matter decomposition, and bioremediation. Changes in soil microbial communities resulting from ecosystem management can have significant impacts on ecosystem dynamics (Bossio and Scow, 1995). The concerns about the sustainability of the agricultural ecosystem have also increased the interests in soil microbial communities and how they and their functions are affected by environmental factors (Bossio and Scow, 1995).

The relationship between community composition or species richness and ecosystem function has attracted considerable research interest (Jumpponen et al., 2002). Most studies have focused on how different plant species influence soil microbial community composition. It is shown that different plant species can influence the composition and number of soil microorganisms due to variations in the quantity and quality of root exudates (Curl and Truelove, 1986; Bowen and Rovira, 1991; Söderberg et al., 2002). Bardgett et al. (1998) and Wardle et al. (1999) have reported that the abundance, activity, and composition of soil decomposer communities may vary markedly with differ-

\footnotetext{
* Corresponding author. E-mail: bdchen@rcees.ac.cn.
}

ent plant species, or specific functional plant groups such as legumes. Legumes can positively affect the microbial biomass due to high litter quality, that is, litter with a lower $\mathrm{C} / \mathrm{N}$ ratio (Spehn et al., 2000; Scherer-Lorenzen et al., 2003; Bartelt-Ryser et al., 2005). Experiments of mixed versus monocultured plant species have demonstrated that plant mixtures can produce greater plant biomass (DeBell et al., 1997; Forrester et al., 2004), and improve nutrient cycling and soil fertility (Binkley et al., 1992, 2000; Bauhus et al., 2000; Montagnini et al., 2000). The increase in plant biomass in the mixture may have strong effects on soil microbial community. In most terrestrial ecosystems microbial biomass and growth have been shown to increase with increasing carbon input (Smith and Paul, 1990; Van de Geijn and van Veen, 1993; Spehn et al., 2000).

On the other hand, soil water is an important resource for plant growth and microbial activity (Williams and Rice, 2007). Changes in soil moisture may affect the function and structure of the soil microbial community through its effect on osmotic potential, transport of nutrients and energy, and cellular metabolism, as well as on the competitive interactions between microbial species (Harris, 1981; Yancey et al., 1982; Kempf and Bremer, 1998; Williams and Rice, 2007). Different types of microorganisms are differently affected by changing water potential (Todd et 
al., 1999; Griffiths et al., 2003; Drenovsky et al., 2004). For example, Gram-negative bacteria are thought to be sensitive to the changes in soil moisture, whereas, fungi are considered more tolerant to low water availability (Harris, 1981; Nesci et al., 2004; Williams and Rice, 2007). However, in planted soil, the effects of soil moisture on plants will also affect soil microbial community structure. Changes in soil moisture can influence soil microbial community structure via its effects on plant biomass and root exudation. To date only a few studies have been conducted to assess the impact of soil moisture content on soil microbial communities, as influenced by plant community composition (Lundquist et al., 1999; Söderberg et al., 2002; Fierer et al., 2003; Griffiths et al., 2003), although plant diversity is the rule in natural ecosystems rather than the exception of cultivated grasslands.

Soil water availability is an important factor limiting plant growth and ecosystem restoration on the Loess Plateau in Dingxi City, Gansu Province, China. To accelerate the ecological restoration, it is important to understand the effects of soil moisture on plant growth and competitiveness, and the changes in soil microbial communities. Therefore, this study aimed to investigate soil microbial communities of four different plants under different soil moisture contents. The authors have addressed the following hypotheses: (1) soil moisture content affects plant growth and nutrient uptake; (2) plant growth and community composition affect soil microbial community structure; (3) the effects of soil moisture on soil microbial community composition are mediated by the plant, hence differ depending on the plant species presented.

\section{Materials and methods}

\subsection{Soil properties}

The soil was collected from the rolling hills region of the Loess Plateau in the Dingxi County $\left(35^{\circ} 57^{\prime} \mathrm{N}\right.$, $\left.104^{\circ} 57^{\prime} \mathrm{W}\right)$, Gansu Province, China. This region is located in the Yellow River valley and is characterized by serious soil erosion and a dry, harsh, and continuous deteriorating environment (Ge et al., 2001). Soil properties were determined according to methods recommended by the Chinese Society of Soil Science (Lu, 1999). The soil texture was: sand $19.1 \%$, silt $78.0 \%$, clay $2.9 \%$. Soil pH $(0.01 \mathrm{~mol} / \mathrm{L}$ $\mathrm{CaCl}_{2}$ ) was 7.96. The soil had the following physicochemical properties on a dry weight basis: organic matter, $0.41 \%$; available $\mathrm{P}$ (extractable with $0.5 \mathrm{~mol} / \mathrm{L} \mathrm{NaHCO}_{3}$ ), 1.21 $\mathrm{mg} / \mathrm{kg}$; and water holding capacity, $19.75 \%$. Prior to the experiment, the soil was fertilized with $150 \mathrm{mgN} / \mathrm{kg}$ soil $\left(\mathrm{NH}_{4} \mathrm{NO}_{3}\right), 100 \mathrm{mgP} / \mathrm{kg}$ soil $\left(\mathrm{KH}_{2} \mathrm{PO}_{4}\right)$, and $150 \mathrm{mgK} / \mathrm{kg}$ soil $\left(\mathrm{KH}_{2} \mathrm{PO}_{4}\right.$ and $\left.\mathrm{K}_{2} \mathrm{SO}_{4}\right)$.

\subsection{Experimental design}

Four different plant species, two legumes, white clover (Trifolium repens Linn., C), and alfalfa (Medicago sativa L., A), and two grasses, sudan grass (Sorghum sudanense Stapf., S) and tall fescue (Festuca arundinacea, F), were selected as test plants representing the two major plant groups. Those four plant species were grown separately $(C$, $\mathrm{A}, \mathrm{S}$, and $\mathrm{F}$, respectively) or in a mixture $(1 \mathrm{C}: 1 \mathrm{~A}: 1 \mathrm{~S}: 1 \mathrm{~F}$, $\mathrm{M})$. Pots without plants were arranged as controls (CK). Plant seeds were pregerminated in Petri dishes at $25^{\circ} \mathrm{C}$ and then sown in plastic pots containing $1.5 \mathrm{~kg}$ air-dry soil. The plant seedlings were thinned to 16 seedlings per pot after emergence for one week. The mixed treatment consisted of four seedlings of each species. Two soil moisture regimes, $55 \%$ or $80 \%$ water holding capacity (WHC), were maintained by regular weighing. As a result, there were totally 12 treatments. Three replicates were arranged for each treatment.

The experiment was conducted in the glasshouse of Research Center for Eco-Environmental Sciences, the Chinese Academy of Sciences and the plants grew for eight weeks under natural light conditions with no supplementary illumination. During the period of plant growth the day temperature ranged from 20 to $30^{\circ} \mathrm{C}$ and the night temperature from 10 to $20^{\circ} \mathrm{C}$.

\subsection{Soil and plant sampling}

Two months after sowing, the plants were harvested. The entire soil which was shaken to separate roots from the soil, from each pot was placed in a plastic bag. The plant roots and shoots were washed free of soil with tap water and distilled water. The soil was homogenized by $2 \mathrm{~mm}$ sieve to remove visible plant roots from the soil. The soil for phospholipid fatty acid (PLFA) analysis was frozen immediately at $-20^{\circ} \mathrm{C}$ and then freeze-dried (FD-1 Vacuum Freezing \& Drying apparatus, China).

Shoots and roots were dried at $70^{\circ} \mathrm{C}$ for $48 \mathrm{~h}$ to determine dry weights, and then ground into fine powder. The grounded plant samples were digested with a mixture of hydrogen peroxide and sulfuric acid. The total $\mathrm{N}$ concentrations were determined using the Kjeldahl method (Bremner, 1965). The concentrations of $\mathrm{P}$ element were analyzed by inductively coupled plasma-optical emission spectroscopy (ICP-OES, Optima 2000DV, Perkin Elmer, USA). Root $\mathrm{C}$ was determined using an elemental analyzer (Vario EL III, Elementar Company, Germany).

\subsection{Phospholipid fatty acid (PLFA) analysis}

The PLFA extraction procedure followed that described by Bardgett et al. (1996), which was developed from the method of Bligh and Dyer (1959). The separated PLFAs were subjected to a mild alkaline methanolysis at $50^{\circ} \mathrm{C}$, and the resulting fatty acid methyl esters were detected with an Agilent 6820 gas chromatograph (GC) equipped with a HP-5 MS capillary column $(0.32 \mathrm{~mm} \times 30 \mathrm{~m}$, $0.25 \mu \mathrm{m}$ film thickness) and a flame ionization detector (FID), using a standard qualitative bacterial acid methyl ester mixture that ranged from C11 to C20 (Matreya Inc., USA), as an external standard. The fatty acid nomenclature used was described by Frostegård et al. (1993a, 1993b). The branched, saturated PLFAs were chosen to represent Gram-positive bacteria (O'Leary and Wilkinson, 1988; Zelles et al., 1995). The monoenoic and cyclopropane unsaturated fatty acids and saturated fatty acids containing the $\mathrm{OH}$ group represented Gram-negative bacteria. The 
unsaturated PLFA 18:2w6, 9 was used as an indicator of fungal biomass (Federle, 1986). The total PLFAs could indicate total soil microbial biomass (Wardle et al., 1999).

\subsection{Diversity index}

Richness and evenness of the PLFAs were calculated according to the formula developed by Begon et al. (1990).

\subsection{Statistical analysis}

The mole percentage of the phospholipid fatty acid values were $\log _{10}$ transformed before principle component analysis (PCA), and then the soil microbial community structure was examined using PCA. Shoot and root biomass, plant nutrient concentrations, shoot/root ratio, root $\mathrm{C} / \mathrm{N}$ ratio, and the biomass of soil microbes were subjected to an univariate general linear model in SPSS 11.5 to determine the significant differences between treatments.

\section{Results}

\subsection{Plant dry weight}

The decrease in soil moisture content significantly decreased plant dry weights (with the exception of the root biomass of white clover in the mixture) (Table 1). The plant biomass of white clover, alfalfa, sudan grass, and tall fescue at $55 \%$ WHC was decreased by $30 \%, 26 \%$, $27 \%$, and $32 \%$, respectively, compared to $80 \%$ WHC. At a given soil moisture, the biomass of white clover and tall fescue in the mixture was reduced compared to that in the monoculture on a comparable basis, whereas, biomass of alfalfa and sudan grass in the mixture was higher (Table 1), particularly at $80 \%$ WHC.

The decrease in soil moisture content also significantly reduced the total plant dry mass per pot. At 55\% WHC, monocultured white clover and tall fescue had a lower total dry mass than that in the mixture, whereas, alfalfa and sudan grass had a higher total dry mass than that in the mixture. At $80 \%$ WHC, the total dry mass of sudan grass was higher than that in the mixture (Table 1).

\subsection{Shoot to root ratio}

The decrease in soil moisture content reduced the shoot to $\operatorname{root}(\mathrm{S} / \mathrm{R})$ ratio of white clover and alfalfa, whereas, the opposite was true for the $\mathrm{S} / \mathrm{R}$ ratio of sudan grass and tall fescue. At a given soil moisture, compared to monoculture, the $S / R$ ratio of alfalfa and sudan grass in the mixture was higher, whereas, that of white clover and tall fescue was lower. Among different monocultured plants, white clover and tall fescue had a higher $\mathrm{S} / \mathrm{R}$ ratio than sudan grass and alfalfa (Table 1).

\subsection{Plant $\mathbf{N}$ and $P$}

The decrease in soil moisture contents significantly increased plant $\mathrm{N}$ concentrations (Table 2), whereas, soil moisture had no effect on plant $\mathrm{P}$ concentrations. At a given soil moisture, alfalfa had a higher $\mathrm{N}$ concentration than all other plant species, whereas, sudan grass had the lowest $\mathrm{N}$ and $\mathrm{P}$ concentrations.

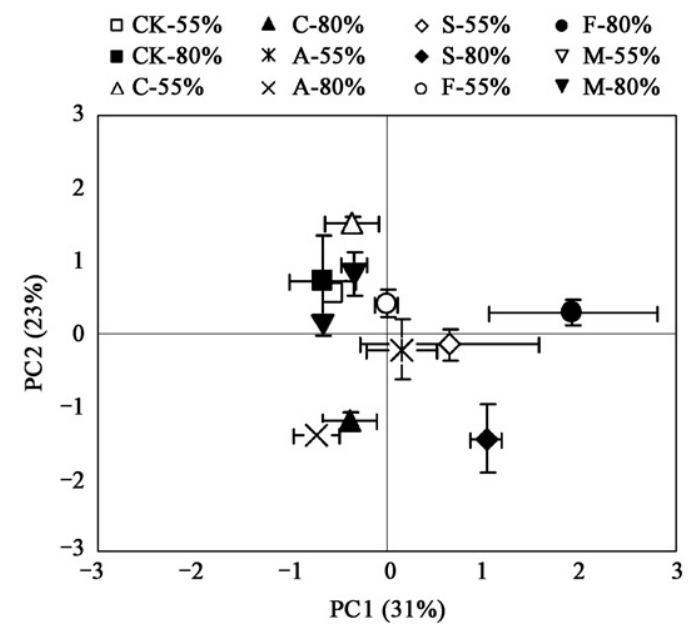

Fig. 1 Principal component (PC) plot of the PLFA profiles of control $(\mathrm{CK})$, white clover $(\mathrm{C})$, alfalfa $(\mathrm{A})$, sudan grass $(\mathrm{S})$, tall fescue $(\mathrm{F})$, and plant mixtures (M) at $55 \%$ or $80 \%$ water holding capacity. Bars indicate standard errors $(n=3)$.

Table 1 Total biomass, shoot biomass, and root biomass (dry weight) of white clover (C), alfalfa (A), sudan grass (S), tall fescue (F), in monoculture and mixtures (M) at $55 \%$ or $80 \%$ water holding capacity (WHC) after plant growth for two months

\begin{tabular}{|c|c|c|c|c|c|c|c|c|c|c|c|c|}
\hline \multirow{2}{*}{$\begin{array}{l}\text { Soil } \\
\text { moisture }\end{array}$} & \multicolumn{2}{|c|}{$\begin{array}{l}\text { Shoot } \\
\text { (mg/plant) }\end{array}$} & \multicolumn{2}{|c|}{$\begin{array}{c}\text { Root } \\
\text { (mg/plant) }\end{array}$} & \multicolumn{2}{|c|}{$\begin{array}{c}\text { Total } \\
\text { (mg/plant) }\end{array}$} & \multicolumn{2}{|c|}{$\begin{array}{c}\text { Total } \\
\text { (g/pot) } \\
\end{array}$} & \multicolumn{2}{|c|}{$\begin{array}{l}\mathrm{S} / \mathrm{R} \text { ratio } \\
(\mathrm{mg} / \mathrm{mg}) \\
\end{array}$} & \multicolumn{2}{|c|}{$\begin{array}{c}\text { Decrease in total } \\
\text { plant dw }(\%)\end{array}$} \\
\hline & $55 \%$ & $80 \%$ & $55 \%$ & $80 \%$ & $55 \%$ & $80 \%$ & $55 \%$ & $80 \%$ & $55 \%$ & $80 \%$ & $55 \%$ & $80 \%$ \\
\hline $\mathrm{C}$ & $160 \pm 7$ & $243 \pm 7$ & $57 \pm 4$ & $69 \pm 4$ & $218 \pm 11$ & $312 \pm 6$ & $3.5 \pm 0.2$ & $5.0 \pm 0.1$ & $2.8 \pm 0.1$ & $3.6 \pm 0.2$ & & 30 \\
\hline A & $191 \pm 2$ & $308 \pm 7$ & $193 \pm 3$ & $209 \pm 4$ & $384 \pm 5$ & $517 \pm 10$ & $6.2 \pm 0.1$ & $8.3 \pm 0.2$ & $1.0 \pm 0.0$ & $1.5 \pm 0.0$ & & 26 \\
\hline $\mathrm{S}$ & $324 \pm 2$ & $402 \pm 13$ & $197 \pm 16$ & $316 \pm 16$ & $521 \pm 16$ & $718 \pm 7$ & $8.3 \pm 0.3$ & $11.5 \pm 0.1$ & $1.7 \pm 0.1$ & $1.3 \pm 0.1$ & & 27 \\
\hline $\mathrm{F}$ & $211 \pm 2$ & $290 \pm 18$ & $78 \pm 2$ & $140 \pm 15$ & $290 \pm 1$ & $430 \pm 32$ & $4.6 \pm 0.0$ & $6.9 \pm 0.5$ & $2.7 \pm 0.1$ & $2.1 \pm 0.1$ & & 32 \\
\hline Mix & & & & & & & $5.8 \pm 0.2$ & $9.0 \pm 0.6$ & & & & \\
\hline $\mathrm{MC}$ & $61 \pm 6$ & $92 \pm 3$ & $42 \pm 5$ & $29 \pm 3$ & $103 \pm 8$ & $122 \pm 6$ & & & $1.8 \pm 0.2$ & $3.1 \pm 0.2$ & & 16 \\
\hline MA & $228 \pm 19$ & $388 \pm 29$ & $156 \pm 15$ & $210 \pm 19$ & $383 \pm 30$ & $598 \pm 48$ & & & $1.5 \pm 0.1$ & $1.7 \pm 0.1$ & & 36 \\
\hline MS & $458 \pm 58$ & $796 \pm 34$ & $197 \pm 25$ & $475 \pm 76$ & $655 \pm 84$ & $1,271 \pm 97$ & & & $2.4 \pm 0.0$ & $1.7 \pm 0.2$ & & 49 \\
\hline $\mathrm{MF}$ & $192 \pm 3$ & $223 \pm 19$ & $88 \pm 2$ & $128 \pm 11$ & $279 \pm 6$ & $352 \pm 30$ & & & $1.8 \pm 0.4$ & $1.7 \pm 0.0$ & & 21 \\
\hline \multicolumn{13}{|c|}{ Significance by analysis of variance } \\
\hline Water $(\mathrm{W})$ & \multicolumn{2}{|c|}{$P<0.001$} & \multicolumn{2}{|c|}{$P<0.001$} & \multicolumn{2}{|c|}{$P<0.001$} & \multicolumn{2}{|c|}{$P<0.001$} & \multicolumn{2}{|c|}{ NS } & & \\
\hline Plant (P) & \multicolumn{2}{|c|}{$P<0.001$} & \multicolumn{2}{|c|}{$P<0.001$} & \multicolumn{2}{|c|}{$P<0.001$} & \multicolumn{2}{|c|}{$P<0.001$} & \multicolumn{2}{|c|}{$P<0.001$} & & \\
\hline $\mathrm{W} \times \mathrm{P}$ & \multicolumn{2}{|c|}{$P<0.01$} & \multicolumn{2}{|c|}{$P<0.001$} & \multicolumn{2}{|c|}{$P<0.001$} & \multicolumn{2}{|c|}{$P<0.05$} & \multicolumn{2}{|c|}{$P<0.001$} & & \\
\hline
\end{tabular}

MC: white clover in mixtures; MA: alfalfa in mixtures; MS: sudan grass in mixtures; MF: tall fescue in mixtures. NS: not significant. Data were presented as means of three replicates \pm standard errors. 
Table 2 The concentrations of $\mathrm{N}, \mathrm{P}$, and root $\mathrm{C} / \mathrm{N}$ ratio of white clover (C), alfalfa (A), sudan grass (S), and tall fescue (F) in monoculture and mixtures $(\mathrm{M})$ at $55 \%$ or $80 \%$ water holding capacity after plant growth for two months

\begin{tabular}{|c|c|c|c|c|c|c|}
\hline \multirow[b]{2}{*}{ Soil moisture } & \multicolumn{2}{|c|}{ Root $\mathrm{C} / \mathrm{N}$ ratio } & \multicolumn{2}{|c|}{$\mathrm{N}(\mathrm{g} / \mathrm{kg})$} & \multicolumn{2}{|c|}{$\mathrm{P}(\mathrm{g} / \mathrm{kg})$} \\
\hline & $55 \%$ & $80 \%$ & $55 \%$ & $80 \%$ & $55 \%$ & $80 \%$ \\
\hline $\mathrm{C}$ & $16.6 \pm 0.6$ & $19.0 \pm 0.4$ & $49.1 \pm 1.8$ & $33.7 \pm 1.2$ & $5.6 \pm 0.1$ & $4.9 \pm 0.4$ \\
\hline A & $17.5 \pm 0.2$ & $18.6 \pm 0.5$ & $57.3 \pm 2.8$ & $51.0 \pm 2.6$ & $4.8 \pm 0.1$ & $4.2 \pm 0.2$ \\
\hline $\mathrm{S}$ & $33.6 \pm 0.4$ & $36.4 \pm 1.6$ & $27.5 \pm 1.7$ & $22.5 \pm 0.5$ & $2.9 \pm 0.1$ & $3.2 \pm 0.1$ \\
\hline $\mathrm{F}$ & $27.7 \pm 3.0$ & $35.1 \pm 2.6$ & $41.9 \pm 4.9$ & $34.6 \pm 1.6$ & $4.6 \pm 0.2$ & $4.9 \pm 0.2$ \\
\hline MC & $18.9^{\mathrm{a}}$ & $23.3^{\mathrm{a}}$ & $40.4 \pm 1.3$ & $36.7 \pm 1.5$ & $4.4 \pm 0.3$ & $5.3 \pm 0.2$ \\
\hline MA & $20.1 \pm 1.4$ & $19.4 \pm 1.1$ & $51.8 \pm 1.3$ & $51.6 \pm 0.9$ & $4.8 \pm 0.2$ & $4.2 \pm 0.1$ \\
\hline MS & $30.5 \pm 1.4$ & $39.6 \pm 1.8$ & $27.8 \pm 0.8$ & $21.6 \pm 0.8$ & $3.7 \pm 0.2$ & $2.9 \pm 0.1$ \\
\hline $\mathrm{MF}$ & $27.3 \pm 2.4$ & $32.5 \pm 1.4$ & $43.6 \pm 1.9$ & $31.2 \pm 2.9$ & $4.5 \pm 0.1$ & $4.9 \pm 0.1$ \\
\hline \multicolumn{7}{|c|}{ Significance by analysis of variance } \\
\hline Water (W) & \multicolumn{2}{|c|}{$P<0.001$} & \multicolumn{2}{|c|}{$P<0.001$} & \multicolumn{2}{|c|}{ NS } \\
\hline Plant (P) & \multicolumn{2}{|c|}{$P<0.001$} & \multicolumn{2}{|c|}{$P<0.001$} & \multicolumn{2}{|c|}{$P<0.001$} \\
\hline $\mathrm{W} \times \mathrm{P}$ & \multicolumn{2}{|c|}{ NS } & \multicolumn{2}{|c|}{$P<0.05$} & \multicolumn{2}{|c|}{$P<0.001$} \\
\hline
\end{tabular}

MC, MA, MS, and MF are the same as that in Table $1 .{ }^{\text {a }}$ Individual plant biomass of white clover in the mixture is very small, therefore, the three replicates were pooled. NS: not significant. Data are presented as means of three replicates \pm standard errors.

\section{$2.4 \operatorname{Root} \mathrm{C} / \mathrm{N}$ ratio}

Water deficit decreased the root $\mathrm{C} / \mathrm{N}$ ratio (Table 2). At a given soil moisture, the legumes (white clover and alfalfa) had a lower root $\mathrm{C} / \mathrm{N}$ ratio than the grasses (sudan grass and tall fescue). The root $\mathrm{C} / \mathrm{N}$ ratio was similar in monoculture and plant mixture.

\subsection{Principal component analysis (PCA) by PLFA pro- files}

Principal components 1 and 2 explained $31 \%$ and $23 \%$ of the overall variance in data, respectively (Fig.1). Soil moisture affected the microbial community structure in soil with plants, whereas, no effect was found in soil without plants. Under both soil moisture regimes, the microbial community composition of the mixture was similar to that of the unplanted soil or white clover and alfalfa monocultures, but different from that of the grass monocultures. At $55 \%$ WHC, the differences in microbial community composition between the monocultures were less pronounced than at $80 \%$ WHC. The difference between the microbial community composition of the mixture compared to the grass monocultures was more pronounced at $80 \%$ WHC. At $80 \%$ WHC, microbial community composition of the legumes was clearly different from those of grasses along PC1. The microbial community composition of the two legumes was similar, whereas, it differed between the grasses (Fig.1).
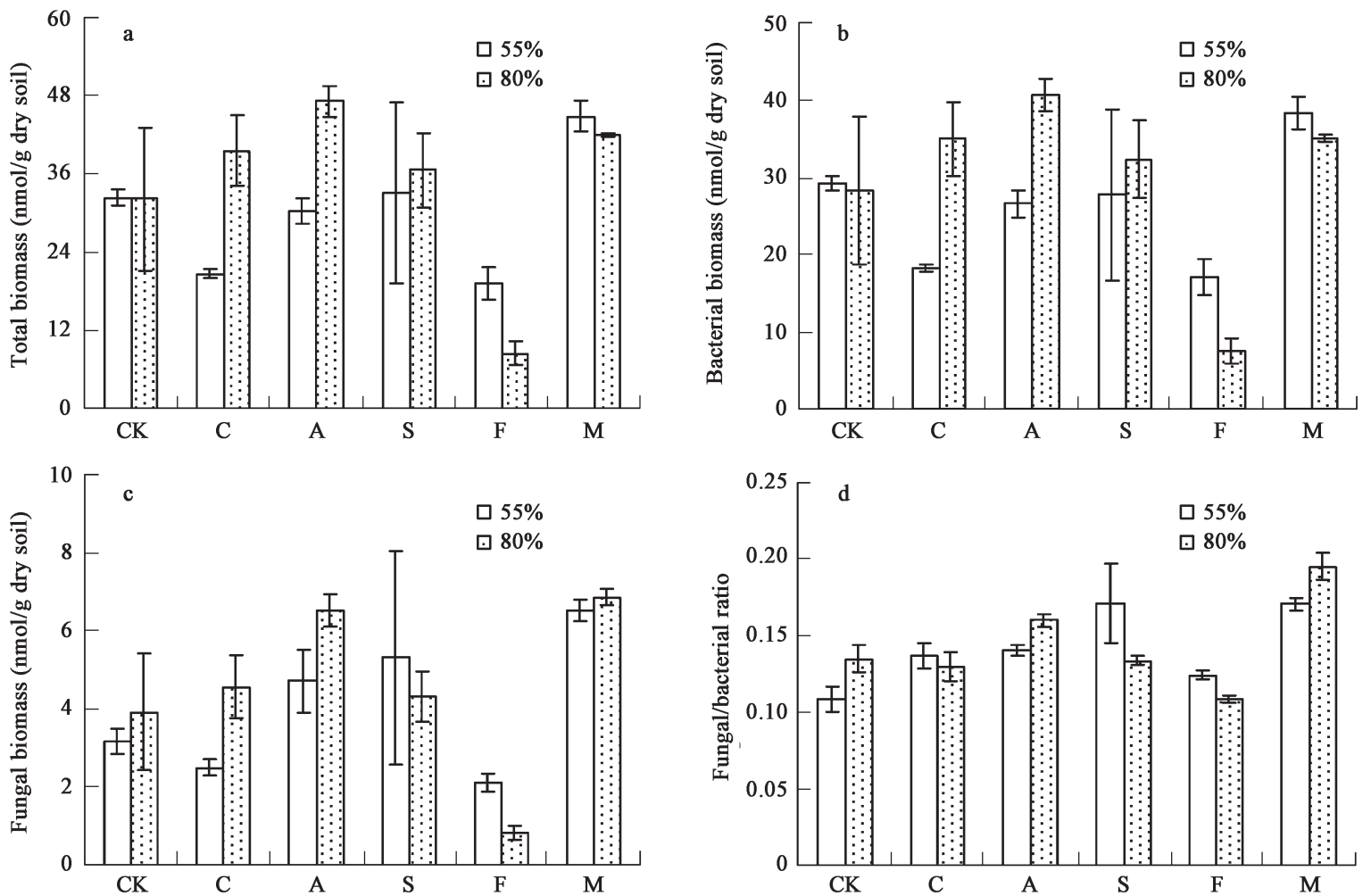

Fig. 2 Total biomass (a), bacterial biomass (b), fungal biomass (c), and fungal/bacterial ratio (d) of the microbial communities from control (CK), white clover (C), alfalfa (A), sudan grass $(\mathrm{S})$, tall fescue $(\mathrm{F})$, and plant mixtures $(\mathrm{M})$ at $55 \%$ or $80 \%$ water holding capacity. Bars above the columns indicate standard errors $(n=3)$. 


\subsection{Microbial biomass}

Soil moisture content had no effect on the total PLFAs, bacterial PLFAs, and fungal PLFAs in the soil without plants and planted with sudan grass. Compared to $80 \%$ WHC, the concentrations of total PLFAs, bacterial PLFAs, and fungal PLFAs were lower at 55\% WHC in soil with legumes, and the contrary in soil with tall fescue. Lower soil moisture also increased the total PLFAs and bacterial PLFAs in the mixture (Figs.2a, 2b and 2c). Total microbial biomass and bacterial and fungal biomass differed significantly between plant species (Table 3). The total PLFAs, bacterial PLFAs, and fungal PLFAs in soil with legumes were higher than those in soil with tall fescue. Compared to tall fescue in the monoculture, the mixture had a higher total microbial biomass and bacterial and fungal biomass, at both soil moisture regimes. However, compared to the legumes in the monoculture, the total microbial biomass and the bacterial and fungal biomass in the mixture were higher only at $55 \%$ WHC.

The decrease in soil moisture content decreased the fungal/bacterial ratio in the unplanted soil and in the soil with alfalfa and the mixture, but enhanced the ratio in the soil with grasses. The mixture had a higher fungal/bacterial ratio compared to the monocultures (Fig.2d).

Table 3 Statistics from the analysis of variance for parameters of soil microbial biomass

\begin{tabular}{|c|c|c|c|c|}
\hline & Total PLFAs & $\begin{array}{l}\text { Bacterial } \\
\text { PLFAs }\end{array}$ & $\begin{array}{l}\text { Fungal } \\
\text { PLFAs }\end{array}$ & $\begin{array}{l}\text { Fungal/bacterial } \\
\text { ratio }\end{array}$ \\
\hline Water $(\mathrm{W})$ & NS & NS & NS & NS \\
\hline Plant (P) & $P<0.01$ & $P<0.01$ & $P<0.01$ & $P<0.001$ \\
\hline $\mathrm{W} \times \mathrm{P}$ & NS & NS & NS & $P<0.05$ \\
\hline
\end{tabular}

NS: not significant.

\subsection{Diversity index}

PLFA richness and evenness were not significantly affected by soil moisture, but were higher in grasses than those in legumes or in the mixture at $80 \%$ WHC (data not shown).

\section{Discussion}

In agreement with other studies (Høgh-Jensen and Schjoerring, 1997; Lucero et al., 1999; Steenwerth et al., 2003), decreasing soil moisture content decreased root and shoot growth, with the reduction in root dry weight being less pronounced than in shoots. In monoculture plants, the percentage decrease in total plant biomass due to lower soil moisture was greater in white clover and tall fescue plants than in alfalfa and sudan grass (Table 1). This indicated that white clover and tall fescue were more sensitive to soil moisture changes. These results were supported by the data of the $S / R$ ratio. At low soil moisture, the white clover and tall fescue plants had a higher $S / R$ ratio than alfalfa and sudan grass, indicating a strong allocation of biomass to shoots, which made them less tolerant to low soil moisture. However, the percentage decrease in the total plant biomass in the mixture was different, being less obvious for white clover and tall fescue than for alfalfa and sudan grass (Table 1), suggesting that tolerance to low soil moisture of monocultures cannot be used to predict the effects on plant growth in plant communities.

Increasing soil moisture significantly decreased plant $\mathrm{N}$ concentration, which could be related to the dilution effects. Alfalfa had a higher $\mathrm{N}$ concentration due to its $\mathrm{N}$-fixing ability and great root biomass. Although white clover would also be able to fix $\mathrm{N}_{2}$, its overall poor growth compared to the other plant species suggested that it was poorly adapted to the test soil. Element concentrations of the plants in the monoculture were similar to those in the mixture (Table 2). Hence, nutrient uptake by a given species appeared to be little affected by other species in this experiment.

Soil moisture has no effect on microbial community composition and microbial biomass in soil without plants, but has significant effects on those in soil with plants (Fig.1). Thus, the effects of soil moisture content on microbial community and microbial biomass appear to have been mediated by the plants, which thus strongly support the authors' hypothesis. The results showed that differences in microbial community composition between plant species are less pronounced at low soil moisture than at high soil moisture.

Microbial community composition for legumes differed from that of the grasses, which could be due to lower root $\mathrm{C} / \mathrm{N}$ ratio of the legumes (Table 2). Another explanation could be the greater root exudation rate of legumes compared to nonlegumes or specific root exudates of legumes (e.g., flavonoids) (Martin, 1971; Mathesius, 2001). The microbial biomass in the mixture appeared to be more tolerant to low soil moisture compared to monocultures. This was demonstrated by the findings that the microbial biomass in the mixture was not reduced at low soil moisture, where the microbial biomass in the mixture was greater compared to monoculture white clover, alfalfa, and tall fescue. It could be speculated that the decreased exudation of a given compound by one plant species was compensated by increased exudation by another species; hence the variety of root exudates in the soil was maintained.

In the present study, plant species had stronger effects on the soil microbial biomass than soil moisture (Fig.2), emphasizing the importance of plants and their rhizodeposition on soil microorganisms. It was interesting to note that although total plant biomass of white clover was lower than that of alfalfa, both the legumes had a similar soil microbial biomass. This suggested that white clover released a greater percentage of assimilated carbon into the soil, either as root exudates or slaughtered root cells. Tall fescue supported the lowest soil microbial biomass among all plant species although the total plant dry weight of tall fescue was higher than that of white clover. On the other hand, sudan grass with the greatest total plant dry weight and the highest root $\mathrm{C} / \mathrm{N}$ ratio had a similar microbial biomass as the much smaller white clover with a low $\mathrm{C} / \mathrm{N}$ ratio. Hence, across the plant species there is no clear relationships between plant dry mass or root 
$\mathrm{C} / \mathrm{N}$ ratio and the microbial biomass. Lower soil moisture decreased microbial biomass in the legumes, but increased it in tall fescue (Fig.2). It could only be speculated that lower soil moisture could have increased root exudation in tall fescue, whereas, it was decreased in the legumes. Another possible explanation was that a decrease in the root $\mathrm{C} / \mathrm{N}$ ratio at lower soil moisture was more pronounced in tall fescue than in the legumes. Surprisingly, the change in soil bacterial and fungal biomass was very similar with decreasing soil moisture. Hence, there was no indication that fungi were more tolerant to low soil moisture than bacteria, which was inconsistent with the previous results (Harris, 1981; Nesci et al., 2004; Williams and Rice, 2007).

Compared to monoculture plants, the shoot and root biomass of sudan grass and alfalfa in the mixture were increased, whereas, the contrary occurred in the case of white clover and tall fescue. Sudan grass and alfalfa had a large root biomass, which could make them more competitive for nutrients and water when grown in the mixture with the other two plant species (Table 1).

The microbial community composition of the plant mixture was on the left hand side of the PCA plot, which indicated that the microbial community of the mixture was more similar to that of the legumes than the grasses, particularly at $80 \%$ WHC. This showed that legumes had a dominating effect on the microbial community composition and could be considered as the keystone species with regard to plant-microbial interactions. The greater microbial biomass in a soil planted with several plant species at low soil moisture suggested that a plant mixture would be able to maintain more favorable conditions for soil microorganisms than a single species.

\section{Conclusions}

The present study indicated that low soil moisture content decreased the growth of all plant species, with alfalfa and sudan grass in the monoculture being less affected than white clover and tall fescue. This suggested that alfalfa and sudan grass were more suitable for revegetation of the degraded soils in the Chinese Loess Plateau. The results also indicated that the mixture with several plant species changed the tolerance of plants to drought stress. Interestingly, the plant mixture appeared to increase the tolerance of the two plant species that were less affected in the monoculture. Also the total plant dry weight per pot was greater in the mixture than in the monoculture of the two plant species (white clover and tall fescue), suggesting that revegetation could be more successful when a plant mixture was used. The soil with legumes had more abundant bacteria and fungi, indicating that legumes could be important in restoring the ecological function in the Chinese Loess Plateau. The greater microbial biomass in the soil with the four plants compared to the monocultures suggested that mixed plant communities provided more favorable conditions for soil microbes, particularly those with low soil moisture content, which could also enhance nutrient cycling and thereby revegetation success.

\section{Acknowledgments}

This work was supported by the National Natural Science Foundation of China (No. 40621061) and the National Basic Research Program (973) of China (No. 2005CB121105). The authors would like to thank Prof. Zhu Yong-Guan for his critical comments on the manuscript.

\section{References}

Bardgett R D, Hobbs P J, Frostegård A, 1996. Changes in soil fungal: bacterial biomass ratios following reductions in the intensity of management of an upland grassland. Biol Fertil Soil, 22: 261-264.

Bardgett R D, Wardle D A, Yeates G W, 1998. Linking aboveground and below-ground interactions: how plant responses to foliar herbivory influence soil organisms. Soil Biol Biochem, 30: 1867-1878.

Bartelt-Ryser J, Joshi J, Schmid B, Brandl H, Balser T, 2005. Soil feedbacks of plant diversity on soil microbial communities and subsequent plant growth. Perspect Plant Ecol Evol Syst, 7: $27-49$.

Bauhus J, Khanna P K, Menden N, 2000. Aboveground and belowground interactions in mixed plantations of Eucalyptus globulus and Acacia mearnsii. Can J Forest Res, 30: 18861894.

Begon M, Harper J L, Townsend C R, 1990. Ecology-Individuals, Populations, Communities (2nd ed.). Oxford: Blackwell Scientific Publications.

Binkley D, Dunkin K A, DeBell D S, Ryan M G, 1992. Production and nutrient cycling in mixed plantations of Eucalyptus and Albizia in Hawaii. Forest Sci, 38: 393-408.

Binkley D, Giardina C, Bashkin M A, 2000. Soil phosphorus pools and supply under the influence of Eucalyptus saligna and nitrogen-fixing Albizia falcaltaria. Forest Ecol Manag, 128: 241-247.

Bligh E G, Dyer W J, 1959. A rapid method of total lipid extraction and purification. Can J Biochem Physiol, 37: 911-917.

Bossio D A, Scow K M, 1995. Impact of carbon and flooding on the metabolic diversity of microbial communities in soils. Appl Environ Microbiol, 61: 4043-4050.

Bowen G D, Rovira A D, 1991. The rhizosphere: the hidden half of the hidden half. In: Plant Roots: the Hidden Half (Waisel Y., Eshel A., Kafka U., eds.). New York: Marcel Dekker. 641-669.

Kempf B, Bremer E, 1998. Uptake and synthesis of compatible solutes as microbial stress responses to high-osmolality environments. Arch Microbiol, 170: 319-330.

Bremner J M, 1965. Total nitrogen. In: Methods of Soil Analysis Part 2-Chemical and Microbiological Properties Number 9 in the Series Agronomy (Black C. A., Evans D. D., Ensminger L. E., White J. L., Clark F. E., Dinauer R. C., eds.). American Society of Agronomy, Madison, WI. 11491178.

Curl E A, Truelove B, 1986. The Rhizosphere. Berlin: Springer.

DeBell D S, Cole T C, Whitesell C D, 1997. Growth, development, and yield of pure and mixed stands of Eucalyptus and Albizia. Forest Sci, 43: 286-298.

Drenovsky R E, Vo D, Graham K J, Scow K M, 2004. Soil water content and organic carbon availability are major determinants of soil microbial community composition. Microbial Ecol, 48: 424-430. 
Federle T W, 1986. Microbial distribution in the soil-new techniques. In: Perspectives in Microbial Ecology (Megusar F., Gantar M., eds.). Slovene Society for Microbiology, Ljubljana, Slovenia. 493-498.

Fierer N, Schimel J P, Holden P A, 2003. Influence of drying rewetting frequency on soil bacterial community structure. Microbial Ecol, 45: 63-71.

Forrester D I, Bauhus J, Khanna P K, 2004. Growth dynamics in a mixed-species plantation of Eucalyptus globulus and Acacia mearnsii. Forest Ecol Manag, 193: 81-95.

Frostegård Å, Bååth E, Tunlid A, 1993a. Shifts in the structure of soil microbial communities in limed forests as revealed by phospholipid fatty acid analysis. Soil Biol Biochem, 25: 723-730.

Frostegård Å, Tunlid A, Bååth E, 1993b. Phospholipid fatty acid composition biomass and activity of microbial communities from two soil types experimentally exposed to different heavy metals. Appl Environ Microbiol, 59: 3605-3617.

Ge T, Chen Q G, Li J, Liang T G, Lu Z J, 2001. Case study on conversion of farmland to grass and forest in Dingxi County, Gansu Province.

Griffiths R I, Whiteley A S, O'Donnell A G, Bailey M J, 2003. Physiological and community responses of established grassland bacterial populations to water stress. Appl Environ Microbiol, 69: 6961-6968.

Harris R F, 1981. Effect of water potential on microbial growth and activity. In: Water Potential Relations in Soil Microbiology (Parr J. F., Gardner W. R., Elliott L. F., eds.). Madison, WI: ASA. 23-95.

Høgh-Jensen H, Schjoerring J K, 1997. Interactions between white clover and ryegrass under contrasting nitrogen availability: $\mathrm{N}_{2}$ fixation, $\mathrm{N}$ fertilizer recovery, $\mathrm{N}$ transfer and water-use efficiency. Plant Soil, 197: 187-199.

Jumpponen A, Högberg P, Huss-Danell K, Mulder C P H, 2002. Interspecific and spatial differences in nitrogen uptake in monocultures and two-species mixtures in North European grasslands. Funct Ecol, 16: 454-461.

Lucero D W, Grieu P, Guckert A, 1999. Effects of water deficit and plant interaction on morphological growth parameters and yield of white clover (Trifolium repens $\mathrm{L}$.) and ryegrass (Lolium perenne L.) mixtures. Eur J Agron, 11: 167-177.

Lundquist E J, Scow K M, Jackson L E, Uesugi S L, Johnson C R, 1999. Rapid response of soil microbial communities from conventional, low input, and organic farming systems to a wet/dry cycle. Soil Biol Biochem, 31: 1661-1675.

Lu R K, 1999. Analytical methods for soils and agricultural chemistry. Beijing: China Agricultural Science and Technology Press.

Martin J K, 1971. ${ }^{14} \mathrm{C}$-labelled material leached from the rhizoshere of plants supplied with ${ }^{14} \mathrm{CO}_{2}$. Aust J Biol Sci, 24: $1131-1142$.

Mathesius U, 2001. Flavonoids induced in cells undergoing nodule organogenesis in white clover are regulators of auxin breakdown by peroxidase. J Exp Bot, 52: 419-426.

Montagnini F, 2000. Accumulation in above-ground biomass and soil storage of mineral nutrients in pure and mixed plantations in a humid tropical lowland. Forest Ecol Manag, 134: $257-270$.

Nesci A, Etcheverry M, Magan N, 2004. Osmotic and matric potential effects on growth, sugar alcohol and sugar accumulation by Aspergillus section Flavi strains from Argentina. J Appl Microbiol, 96: 965-972.

O'Leary W M, Wilkinson S G, 1988. Gram-positive bacteria. In: Microbial Lipids (Ratledge C., Wilkinson S.G., eds.). Vol 1. London: Academic Press. 117-202.

Scherer-Lorenzen M, Palmborg C, Prinz A, Schulze E D, 2003. The role of plant diversity and composition for nitrate leaching in grasslands. Ecol, 84: 1539-1552.

Smith J L, Paul E A, 1990. The significance of soil microbial biomass estimations. In: Soil Biochemistry (Bollag J., Stotzky G., eds). New York: Marcel Dekker. Vol 6. 357393.

Söderberg K H, Olsson P A, Bääth E, 2002. Structure and activity of the bacterial community in the rhizosphere of different plant species and the effect of arbuscular mycorrhizal colonisation. FEMS Microbiol Ecol, 40: 223-231.

Spehn E M, Joshi J, Schmid B, Alphei J, Körner C, 2000. Plant diversity effects on soil hetertrophic activity in experimental grassland ecosystems. Plant Soil, 224: 217-230.

Steenwerth K L, Jackson L E, Caldern F J, Stromberg M R, Scow K M, 2003. Soil microbial community composition and land use history in cultivated and grassland ecosystems of coastal California. Soil Biol Biochem, 35: 489-500.

Todd T C, Blair J M, Milliken G A, 1999. Effects of altered soil-water availability on a tallgrass prairie nematode community. Appl Soil Ecol, 13: 45-55.

Van de Geijn S C, van Veen J A, 1993. Implications of increased carbon dioxide levels for carbon input and turnover in soils. Vegetatio, 104-105: 283-292.

Wardle D A, Bonner K I, Barker G M, Yeates G W, Nicholson K S, Bardgett R D, Watson R N, Ghani A, 1999. Plant removals in perennial grassland: vegetation dynamics, decomposers, soil biodiversity, and ecosystem properties. Ecol Monogr, 69: 535-568.

Williams M A, Rice C W, 2007. Seven years of enhanced water availability influences the physiological, structural, and functional attributes of a soil microbial community. Appl Soil Ecol, 35: 535-545.

Yancey P H, Clark M E, Hand S C, Bowlus R D, Somero G $\mathrm{N}, 1982$. Living with water-stress-evolution of osmolyte systems. Science, 217: 1214-1222.

Zelles L, Rackwitz R, Bai Q Y, Beck T, Beese F, 1995. Discrimination of microbial diversity by fatty acid profiles of phospholipids and lipopolysaccharides in differently cultivated soils. Plant Soil, 170: 115-122. 